\title{
Silver Tourism and Recreational Activities as Possible Factors to Support Active Ageing and the Resilience of the Tourism Sector
}

\author{
Ana-Maria TALOŞı, 2 , Ana-Irina LEQUEUX-DINCĂ ${ }^{1 *}$, Mihaela PREDA', Camelia SURUGIU3, \\ Alina MARECI1, Iuliana VIJULIE4 \\ *Corresponding author \\ 1 University of Bucharest, Faculty of Geography, Department of Human and Economic Geography, Bucharest, ROMANIA \\ 2 University of Bucharest, Romanian Young Academy, Bucharest, ROMANIA \\ 3 University of Bucharest, Faculty of Business and Administration, Bucharest, ROMANIA \\ 4 University of Bucharest, Faculty of Geography, Department of Regional Geography and Environment, Bucharest, ROMANIA \\ $\triangle$ ana.talos@geo.unibuc.ro (D) https://orcid.org/oooo-0oo3-1370-7825 \\ $\triangle$ ana.dinca@geo.unibuc.ro (D) https://orcid.org/oooo-ooo2-2488-3528 \\ $\triangle$ mihaela.preda@geo.unibuc.ro (1D https://orcid.org/oooo-ooo1-6134-7612 \\ $\triangle$ camelia.surugiu@faa.unibuc.ro (D) https://orcid.org/oooo-0oo2-0393-4015 \\ $\triangle$ alina.mareci@unibuc.ro (D https://orcid.org/oooo-0oo2-6361-60oo
}

$\triangle$ iuliana.vijulie@g.unibuc.ro (D) https://orcid.org/oooo-0oo1-9611-3971

DOI: 10.24193/JSSPSI.2021.8.04

https://doi.org/10.24193/JSSPSI.2021.8.04

K e y w o r d s: leisure travel, seniors, demographic challenges, tourism recovery, Bucharest

\begin{abstract}
A B S T RA C T
Population ageing, affecting both developed and developing countries nowadays, poses new challenges but also represents an opportunity for socio-economic systems in general, and in particular for tourism and recreation. In the light of the recently designed EU silver economy policies, active ageing shapes itself to be an attractive opportunity for the European leisure market. Seriously affected by the COVID-19 health crisis, the tourism sector's resilience depends on the hospitality industry's capacity to adapt, innovate, and respond to society's new demographic challenges. Consequently, new types and forms of tourism and new service technologies should be implemented having in mind an ageing population. This paper used as the main research tool a survey on Bucharest residents aged 65 and over, aiming to identify their main preferences and limitations regarding recreational activities and leisure tourism. The main results identify similarities and differences to findings on European silver tourists and could be further valued by better adapted holiday packages and tourism marketing strategies for Romania. The present research emphasised differences in senior travel preferences and a possible segmentation of silver tourists in Romania (e.g. based on their income, education level), highly suggesting that the elderly's needs have to be addressed by tailor-made products.
\end{abstract}

\section{INTRODUCTION}

The term silver tourism is derived from silver economy and encompasses numerous activities describing an integrated approach to senior tailored leisure activities. Europe's population grows old, inducing significant societal changes and demographic vulnerabilities (Horea-Şerban and Istrate, 2015) determined by the growth of the dependency ratio, the cost of care or the decrease of labour force resources. 
The innovative concept of silver economy targets older adults and includes a vast range of notions and areas of interest related to both opportunities and threats for the worldwide fast ageing populations, wellillustrated by the European landscape. In this context, the need for better social inclusion of older adults through adapted residential and environmental facilities, sustainable health care systems, or a dynamic environment for them to remain active and valued contributors to society are just a few of the concerns expressed by EU policies supporting active and healthy ageing for its elderly population.

The perception of territories as dynamic and continuous processes of social construction and the importance of cultural factors when discussing community' resilience as part of the urban capacity to adapt to socio-economic transformations (Banini and Ilovan, 2021a) points out the necessity to consider the societal dimension in its regional and local context when planning economically sustainable, innovative and adaptive products.

The European silver economy's global importance and growth potential (EC, 2018a) led recently designed EU policies to focus on horizontal and cross-cutting collaboration between all sectors, which could tackle the societal challenges of demographic change by turning them into opportunities. Silver tourism was explicitly mentioned by the European Commission, next to other domains (e.g. mHealth, robotics, ICT technologies, age-friendly built environment, age-friendly education), as a sub-domain with recognised potential for growing the silver economy (Varnai et al., 2018). According to the same study, this sector's further development demands a better targeting of older people by addressing their travel and recreational needs through a more varied EU tourism offer, in order to cope with the low and very low participation degree of seniors in Europe and especially in Romania, in tourism activities.

Tourism and leisure activities are two of the main domains connected to the senior population's active and healthy ageing and occupy a substantial share of the silver economy, given that seniors have greater availability in terms of leisure time compared to their younger peers (Varnai et al., 2018). Furthermore, recreational activities improve their mobility while ensuring their mental, psychological, and physical wellbeing. As technology and healthcare advance and offer transport and mobility solutions for people with reduced capacity and in the context of an increasingly aged Europe, silver tourism represents an important domain of the silver economy.

However, 2020 meant an immense shock for the whole tourism industry induced by the COVID-19 pandemic, as recreation and cultural activities or other consumer-facing sectors were severely affected. Despite the regular exposure of tourism to an extensive range of crises in the past (Dolnicar and Zare, 2020; Gössling, Scott and Hall, 2020), "the nature and unprecedented circumstances and impacts" of this crisis predict "profound and long-term structural and transformational changes to tourism as a socioeconomic activity and industry" (Sigala, 2020, p. 312).

In this context, the present study aims to present silver tourism in Romania as a possible resilient leisure sector within the economic recovery process in the post-COVID-19 years. While questioning its capacity for recovery, the paper aims to analyse the tourism sector's development level and growth potential before the pandemic. In order to achieve its objectives, the study uses complementary methods. The first section depicts the literature review on active and healthy ageing, age-friendly tourism planning, as well as on the travel sector's resilience and the perspectives of silver tourism development in the post-COVID-19 context.

The next section presents Eurostat (2016a) tourism data about older tourists and computed visualised data allowed to reflect Romania's case in a broader European context. The background information was further enriched by focusing on the existing national initiatives before the COVID-19 outbreak that supported social leisure activities and targeted seniors' consumption of recreation services in Romania and Europe. Section four describes the methodology, which centred on a quantitative survey and complementarily on data analysis. Section five presents the main results, namely seniors' perception, their preferences and restrictive factors when discussing leisure tourism and recreational activities. Section six enlarges the discussion of the results, and section seven concludes the paper.

\section{LITERATURE REVIEW}

\subsection{Silver tourism and leisure age-friendly planning as factors for active and healthy ageing}

Ageing and active ageing have become, in recent years, core elements of the economic and social planning policies in the EU, generating innovative ideas and the creation of dedicated partnerships and action groups (EC, 2018b). As they are already facing essential demographic transformations, European countries became more and more concerned about pensions, healthcare, and long-term care systems, which are at risk of becoming financially unsustainable because of the misbalanced economically productive human resources (Eurostat, 2019). Consequently, in the attempt to turn ageing challenges into opportunities, active ageing was embraced by the EU as a new policy 
framework that tries to ensure people live as long as possible, in a less disturbed manner, and contribute to the economy and society in general (Eurostat, 2019).

Besides the European demographic context, ageing is, at present, an evident global phenomenon, sped up in many developing countries ( $\mathrm{Yu}$ and Rosenberg, 2020) and asking for age-friendly policies which promote active and healthy ageing. This explains the WHO initiatives to support age-friendly policy design and good practices. Active ageing aims to extend healthy life expectancy and quality of life as people age (Guillemard and Argoud, 2004; Clarke and Warren, 2007; Walker, 2010; Matei et al., 2018).

The concept is also related to a series of interconnected main determinants: social, economic, healthcare services, behavioural, personal, physical environment, and to gender and culture as cross-cutting dimensions (Fig. 1) (WHO, 2002).

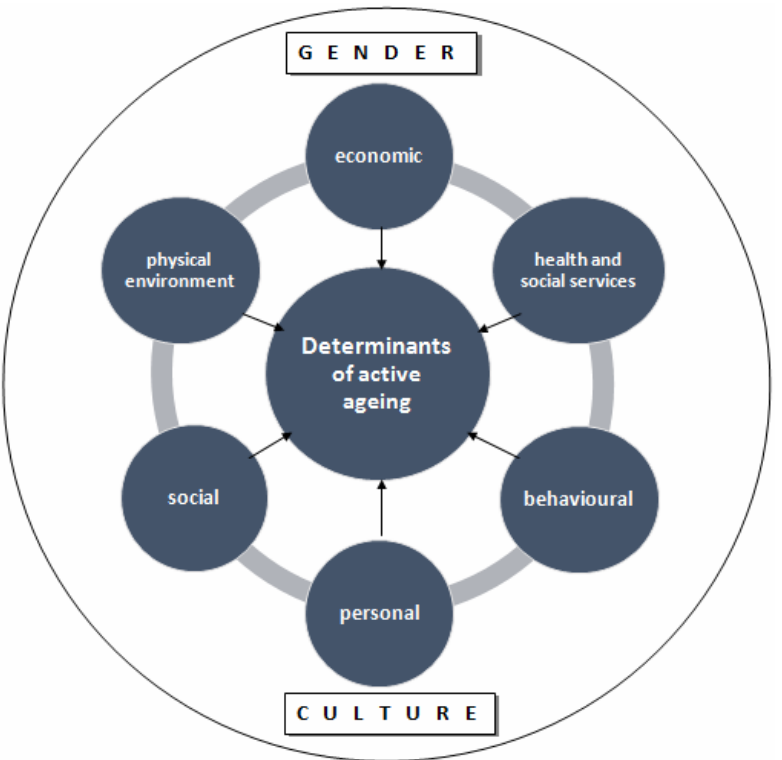

Fig. 1. Active ageing concept and its determinants (adapted from WHO, 2002).

The WHO World Report on Ageing and Health defined healthy ageing as "the process of developing and maintaining the functional ability that enables wellbeing in older age" (WHO, 2015, p. 28). The report underlined that recreation and leisure travelling have a positive impact on all aspects of the elderly's life and combat ageism; while also motivating mobility and social connectedness among people, an idea also reiterated by the recent initiative on the Decade of Healthy Ageing 2020-2030 (WHO, 2019).

Another concern of international organisations about ageing issues is the accessibility for increasingly vulnerable older adults in a changing and challenging environment. Physical accessibility is just one point to be addressed, along with economic accessibility (affordability) of goods and services, health facilities and information. At the EU level, continuous initiatives, with societal inclusion goals for persons with disabilities and the elderly, culminated with the European Accessibility Act, EU directive 2019/882 on the accessibility requirements of products and services (European Parliament and Council, 2019).

An entire age-friendly movement and attempts to create global age-friendly cities and to adapt urban environments to population ageing became more and more apparent worldwide (WHO, 2007; ESPON, 2019). Moreover, 'ageing-in-place' safely and independently became evidence of the elderly's quality of life (Schorr and Khalaila, 2018) and a governing principle (Channer, Hartt and Biglieri, 2020) promoted following sustainability principles in tourism planning (Yusuf et al., 2019). Seniors are thusly considered an important stakeholder for policymakers, and horizontal crosssectoral collaboration became an administrative priority.

Long-term sustainable planning policies should turn to strategic and innovative elements, which also represent important issues of the policymaking framework (Chao-zhi and Xiao-tao, 2017). Sustainable tourism planning is undoubtedly multi-objective and multi-dimension oriented (Arbolino et al., 2021), and tourists themselves are a key stakeholder who should be empowered by the communicative paradigm in this multi-decision-making process (Kantola et al., 2018). Consequently, age-friendly tourism planning and tailormade products and brands for silver tourism in the EU and Romania should integrate successful elements and practices from the existing tourism planning approaches (Rahmafitria et al., 2020) while considering silver consumers' wishes for offers which address them.

In a society dominated by productivity, either as a counterpart to late employment or simply describing an active lifestyle oriented towards travelling as a choice to spend free time, silver tourism shapes itself as a factor to resist negative stereotypes about old age (Wearing, 1995). Older adults in developed countries can provide a valuable tourism market, even for the more physically demanding segments of leisure tourism (Buckley, 2020). They are emphasised and targeted as an important and growing age group in the consumption of tourism and recreation services in developing post-communist countries (for 'Silver century' brand in Russia, cf. Nikitina and Vorontsova, 2015). Seniors were also particularly approached by a series of dedicated tourism planning project initiatives at the EU level: TOURAGE - Developing Senior Tourism in Remote Regions (TOURAGE report, 2014); ESCAPE Charter and Club initiatives in connection to AGE Platform Europe - the voice of older persons at the EU level (Gheno, 2016); the "silver suitcase" brand and the silver tourist ID-card in SenGoR - Seniors Go Rural project with EuroGites - European Federation of Rural Tourism as main partner in the project (Ehrlich, 2016); support and exchange of good practices for more 
flexible, better adapted and branded active ageing oriented products for senior tourists in SENTour Connect project (Gobin, 2016).

\subsection{The resilience of silver tourism in the COVID-19 context - a possible future to be questioned}

\subsubsection{Tourism challenges in the present COVID-19 pandemic context}

The recent COVID-19 pandemic, which imposed drastic governmental measures and locked down entire countries across the globe, was recognised, by both reference institutions and scientists, as having done enormous damage to the worldwide tourism industry (UNWTO, 2020a; Fotiadis, Polyzos and Huan, 2021) and negatively impacted many different hospitality sectors (Collins-Kreiner and Ram, 2020).

As an economic sector highly vulnerable to numerous and various risks, tourism has regularly met other crises over the past century, including sanitary ones (e.g. mad cow disease / bovine spongiform encephalopathy (BSE) - 2003, the foot and mouth disease (FMD) - 2001, SARS - 2003, MERS - 2015) (Collins-Kreiner and Ram, 2020; Sigala, 2020). However, despite this sector's previously noted capacity to bounce back, the shock produced by COVID-19 is considered unique. Being the first case of a global economic disruption, it caused permanent losses for this sector (Sharma, Thomas and Paul, 2021; Škare, Soriano and Porada-Rochon, 2021).

Tourism cannot exist if tightened travel restrictions are maintained. The World Tourism Organization (UNWTO) estimations of a $60-80 \%$ decline for the yearly international tourist flows expressed at the beginning of the COVID-19 pandemic period (UNWTO, 2020b) were confirmed by the $74 \%$ dropping in international arrivals reported by the UNWTO World Tourism Barometer, determining the same reference organisation to entitle 2020 as the worst year in tourism history (UNWTO, 2020c).

The COVID-19 pandemic induced crisis is a radical challenge for the hospitality industry, and the tourism recovery process would demand important changes regarding future management and planning approaches for this sector. Transformations of future tourism industries would also mean changing tourism planning patterns which should include sustainability and equity elements, climate change mitigation issues, local communities' engagement, and societal wellbeing (Sharma, Thomas and Paul, 2021). Despite some early attempts of resuming tourism activities (Collins-Kreiner and Ram, 2020), the sudden, uncertain, and volatile character of the COVID-19 crisis makes it difficult to provide reliable forecasts for the recovery of tourism demand (Zhang et al., 2021).

\subsubsection{Tourism resilience}

Resilience is seen as "a crisis management tool/strategy for business stability and adaptability to all types of risks" (Sharma, Thomas and Paul, 2021, p. 4), and it requires, besides the capacity to recognise and evaluate the crisis, the coordination and optimal collaboration among local stakeholders, including institutional and governmental efficiency in facing critical events (Collins-Kreiner and Ram, 2020; Sharma, Thomas and Paul, 2021; Škare, Soriano and Porada-Rochon, 2021). Psychological resilience and surpassing the 'travel fear' are also key elements in the recovery period of tourism in a (post)pandemic context (Zheng, Luo and Ritchie, 2021).

Despite some differences induced by the disciplines approaching the issue and the context in which it applies (Brown et al., 2017), the concept of resilience refers to a system's ability to survive disturbance or change (Lee et al., 2020). Its popularisation in economic studies and particular importance for tourism determined the necessity of a more in-depth analysis of resilience's main aspects (e.g. vulnerability, shock absorption, recovery ability) and its territorial, regional perspectives (Romāo, 2020). According to Sharma, Thomas and Paul (2021), the tourism industry's resilience capacity post-COVID-19 would depend on four main factors: government response, technology innovation, local belongingness, and consumer and employee confidence. Governmental policies consisted of short-term financial stimuli and interventions for supporting great tourism actors (e.g. multinational companies or large airports) in order to maintain a certain economic flow and secure social safety nets (Higgins-Desbiolles, 2020). In the long term, ensuring tourism recovery while maintaining social distancing needs to consider other elements such as technology and innovation. These would decrease employment and facilities related costs by using robots and automation technologies (Assaf and Scuderi, 2020).

The COVID-19 pandemic had brought with it various restrictions, including severe ones concerning international travels. As such, people had to replace their international leisure travelling, either with vising friends and relatives or with other destinations close to home (Haywood, 2020). This has stimulated a feeling of local belongingness, a foundation on which the revitalisation of medium-term tourism can build, considering that travelling will be further limited for at least one more year. The restrictions for cross-border movement and the prevalence of local leisure consumption would definitely add more variables to the way in which belonging is negotiated, and placeattachment is perceived (Banini and Ilovan, 2021b). Consumer and employee confidence would also be key determinants for future tourism resorts, and the boost 
in frequency for leisure travelling to local and domestic tourism is more evident than ever (Brouder et al., 2020; Sharma, Thomas and Paul, 2021), dominating international arrivals even for famous traditional attractive inbound destinations (Arbulú et al., 2021).

Resilience in various sectors of the hospitality industry is a demonstrated result of simultaneous application of survival, adaptation and innovation strategies, tourism being considered one of the main economic beneficiaries from the bouncing forward development process (Badoc-Gonzales, Mandigma and Tan, 2021). Innovation strategies through the collaborative networks and smart specialisation of tourism products (Romāo, 2020), while considering territorial and regional perspectives, represent successful methods to overpass crisis and build internal resilience, which is an enhancing attribute for the travel and tourism sector (Badoc-Gonzales, Mandigma and Tan, 2021).

If everybody acknowledges the profound transformative role of this pandemic, tries to avoid unrealistically positive perspectives, and considers the rebound of this sector from previous shocks, general predictions of recovery for the tourism sector from the COVID-19 crisis could be seen as valid (Gössling, Scott and Hall, 2020; Sigala, 2020; Zhang et al., 2021). The context of vaccine development and distribution encourages such an affirmation, despite the reluctance to receive this new health product as a pre-condition of travel (Ma, Heywood and MacIntyre, 2021).

\subsubsection{Travel fear and psychologic resilience}

This pandemic affected to a great extent the elderly population through general restrictions imposed by social distancing measures or the lockdown of the hospitality sector, but also through a particular vulnerability of older adults (aged 65 and older) who present a greater risk of severe illness, hospitalisation or death if diagnosed with COVID-19. Inducing the risk of a highly contagious disease with possible fatal outcomes, especially for seniors, provoked by an uncertain novel virus, rapidly spreading among humans, the COVID-19 pandemics could be categorised as a psycho-social epidemic leading to high intensity of fear and panic among the public (Strong, 1990; Zheng, Luo and Ritchie, 2021).

This is not new or unique as after the SARS outbreak, the impact in terms of consumption was mainly psychological and more serious on older people, negatively affecting tourist demand (Wen, Huimin and Kavanaugh, 2005). The perceived risk connected to a contagious disease in the context of consumer behaviour is a prevalent subject in the tourism research literature (Dolnicar, 2005) and is associated more with fear as horror than fear as nervousness (Fennell, 2017).
The public's fear is further fuelled in this pandemic context by travel restrictions or the governmental mandatory quarantine and isolation measures (Zheng, Luo and Ritchie, 2021). The cognitive aspects of collective imagination and the high media coverage are also elements associated with major global health risks, and the concept of panic may add to the one of travel fear in the current COVID-19 context (Fennell, 2017).

Therefore, individual resilience and the psychological capacity to recover from the pandemic 'travel fear' are key variables for overall tourism recovery and the challenges met by silver tourism innovative products. Fear can also be perceived as a positively appraised stressor determining high emotions and coping behaviours and responses (self or social supported) in order to escape and protect oneself from the threat (Duhachek and Iacobucci, 2005).

As other past pandemic outbreaks have shown (e.g. the EITC - Ebola-induced tourism crisis), healthinduced disasters, often accompanied by negative media coverage, challenge the management of tourism industries in particular emphasising the spillover effects with long term damaging consequences (Novelli et al., 2018). For example, although Ebola cases had a limited spread, all African countries were regarded by potential tourists as risk destinations, and international arrivals to West Africa were still over 50\% short compared to the pre-epidemic values three years after the disease outbreak (WTTC, 2018). When a health crisis creates fear in tourists, people may avoid travel, especially internationally ( $\mathrm{Lu}$ and Wei, 2019). As a direct protective measure to reduce potential risks (Cahyanto et al., 2016), they may be more concerned about their safety and public hygiene (Wen, Huimin and Kavanaugh, 2005).

In Romania, the National Institute of Statistics (NIS) shows that total arrivals decreased from $13,374,943$ in 2019 to $1,762,806$ in 2020. International arrivals also severely decreased from 2,683,748 in 2019 to a six-digit value of 282,643 inbound tourists in 2020 (NIS, 2020a). Reinforced by the COVID-19 pandemic context, domestic tourism concentrated most of the tourism demand (domestic arrivals in Romania represented $83.9 \%$ in the total number of arrivals in 2020 against $79.9 \%$ in 2019) (NIS, 2020b).

\subsubsection{Silver tourism perspectives}

The market of those aged 55 years or older was analysed by research studies to better understand seniors' travel behaviour (Shoemaker, 2000) as their number and consumption power gradually increased, age not representing an obstacle to tourism anymore (TOURAGE report, 2014). The senior segment was reported to control more than half of consumer spending in the US (Hudson, 2010). They have a higher 
capital of free time than in the past, which can be dedicated to a great extent to travel in the postretirement period (Nimrod, 2008).

Marketers initially identified this population group using such labels as "the mature market" (Lazer, 1985), the "older market" (Allan, 1981), and "the senior market” (Shoemaker, 1989). More recent studies have used other phrases such as "the silver market" (Branchik, 2010), which was seen as more appropriate from a marketing perspective and better reflect changing senior patterns (Gobin, 2016).

The contribution of silver tourism to the recovery of the hospitality industry post-COVID-19 in general and in Romania, in particular, may be an important measure to increase public confidence in institutions, reorient the population towards safe tourism consumption and build the economic resilience of this sector. One should notice already existing punctual initiatives for the recovery of the post-COVID19 silver tourism market, such as in Thailand, where several stakeholders promoted long-stay, low price travel packages to European seniors during the 2020 winter season (Thanthong-Knight, 2020).

Recent EU projects have questioned European silver tourists' behaviour and travel patterns and have shown that seniors demand tailor-made products (Ehrlich, 2016; Gheno, 2016; Gobin, 2016) and express obvious variations according to their age segment and individual characteristics (TOURAGE report, 2014). The main travel motivations among the European elderly are relaxation and meeting with family members, while the main barriers are financial reasons, health problems but also the lack of an interesting supply (TOURAGE report, 2014).

The ESCAPE project hierarchised nature and culture, followed by health and wellbeing, as reasons for European seniors' leisure travelling (Gheno, 2016). They mostly travel with a companion, appeal to relatives and friends as their primary source of information about future holidays and leisure destinations and prefer to organise their travel individually but opt, in case of group travel, for support from local senior organisations (TOURAGE report, 2014; Gheno, 2016).

An interesting fact that indicates the untapped potential of silver tourism demand in Europe is that in 2014 more than half of the older Europeans did not participate in tourism (Demunter, 2016). Similarly, in 2018, Varnai et al. showed that over half of the European and over $80 \%$ of the Romanian elders did not participate in tourism activities. When considering the future demand and growth potential for silver tourism and recreational services in Romania, the development of this sector is also theoretically probable. The frequent changes that took place at the institutional level reflected by the incapacity to plan, support and monitor a coordinated development of the leisure sector after 1990, question authorities' capacity to collaborate and innovate and their contribution to a rapid recovery of the industry or to the development of this market segment.

Lacking dedicated studies by scientific literature and research projects, silver tourism in Romania misses important information that should orient tourism planning and marketing towards adapted, innovative, resilient products based on a better segmentation of the older tourism consumers according to their needs and motivations. Consequently, the present study represents a highly necessary approach that answers this research gap from a regional perspective and is a useful departure point for scientists, policymakers, or stakeholders in the hospitality industry.

\section{BACKGROUND INFORMATION}

\subsection{Silver tourism - a new stake for the European and Romanian tourism market}

Even if it is an increasing market with promising growth potential, silver tourism or tourism for seniors is a domain little covered by statistics. One difficulty comes from the fact that there are various definitions for the senior population. The ages of 60 or 65 , roughly equivalent to retirement ages in most developed countries, are said to be the beginning of old age, and many WHO documents often define 'older people' as those over 6o years of age (WHO, 2002; 2019). However, certain studies or projects also include the age group of 55-60 in the silver tourism demand, define it as "the younger old" or the "baby boomers", and consider it to have a substantial potential for offsetting seasonality (Grahnlöf et al., 2016) as the future "seniors".

European elders have a real potential to increase tourism demand throughout the year and reduce seasonality as they tend to be less concentrated in the peak summer months and more active in the shoulder season (spring, autumn) compared with the other age groups (Demunter, 2016).

Proving older adults' growing importance for tourism, Eurostat has recently focused on seniors statistics related to the travel sector, revealing several aspects for the European hospitality market. Therefore, according to Eurostat (2016a), " 1 in 5 tourism nights of EU residents is spent by tourists aged 65 or over”. In 2014, senior tourists already represented the most significant share among different age groups of EU residents (approx. 20\% in the total demand), and the percentages of the following older age groups also showed an important growing potential for silver travellers (Eurostat, 2016a). 
In 2014, Romania registered one of the lowest proportions of people aged 65 or over in total tourism overnights compared to other countries in the EU, reaching only $13 \%$ for senior demand in all tourism overnights. Similar values were registered by Luxembourg or Croatia and surpassed only the figures displayed by Malta (9\%), Bulgaria (10\%), Slovenia (10\%) or the Baltic countries (Fig. 2).

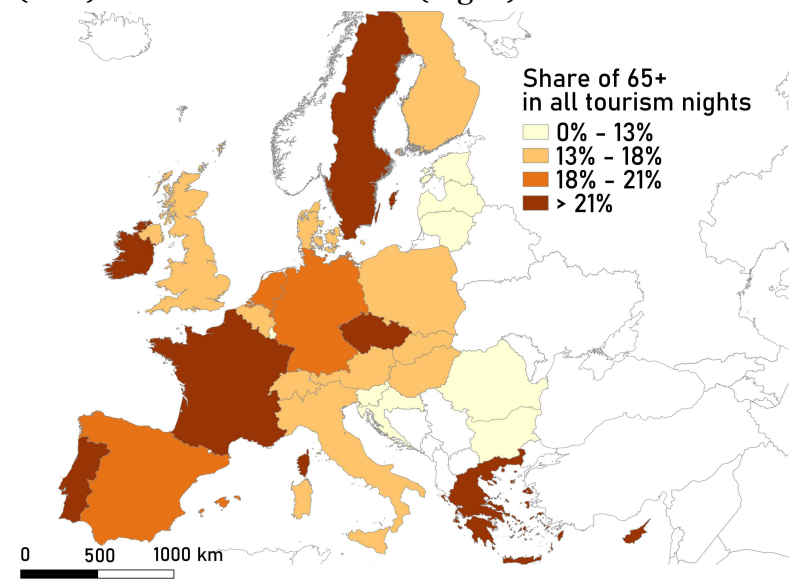

Fig. 2. Share of tourism nights spent by people aged 65 or over in all tourism nights in the EU Member States, 2014 (source: Computed by authors. Data source: Eurostat news release 183/2016 from 26/o9/2016).

The balance between domestic and outbound holidays in favour of domestic trips in the preference of tourists aged 65 and over in Romania showed a similar value to the Czech Republic's (89\%), lower only than Spain's (94\%) and Greece's (92\%) (Fig. 3). The percentage of seniors not participating in tourism activities in Romania is higher than the one displayed by the European average (88.3\% against 51.4\%), overpassed only by Bulgaria (Eurostat, 2016b), and may be explained by the pattern of low-income areas and financial issues linked to the country's peripherality in Europe (TOURAGE report, 2014). This shows that Romania has high potential as a domestic destination and proves that market-oriented products need to be redesigned and reconsidered in the future.

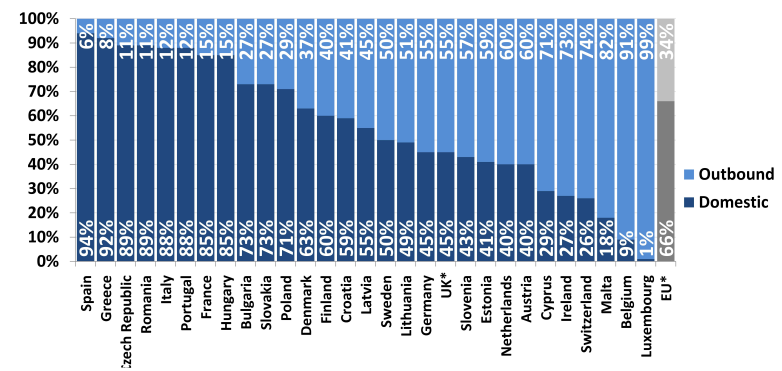

Fig. 3. Weight of tourism nights spent by people aged 65 or over (EU 2014): domestic holidays vs outbound trips (source: Computed by authors. Data source: Eurostat news release 183/2016 from 26/o9/2016).

In terms of tourism expenditure of residents aged 65 or over, there is a clear breakdown between the
Eastern and South-Eastern European countries, on the one hand, and Central and Western European countries, on the other (Fig. 4). Higher prices imposed by a higher purchasing power, the tailored, varied and more generous tourism offer, targeting seniors but also the high number of travellers aged 65 or over, are just a few elements explaining this situation. Across the EU Member States, Romania registered, in 2014, an average per day expenditure of older tourists of $€ 13.8$, slightly overpassing only the Czech Republic (€13.7) (Fig. 4).

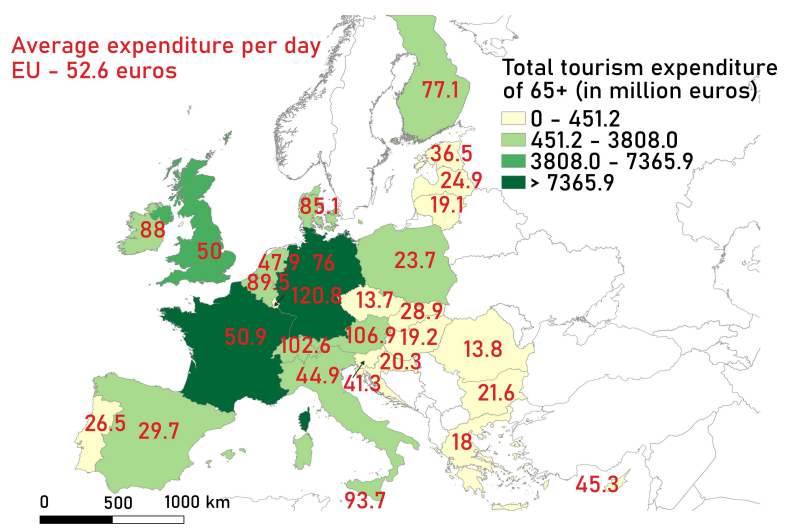

Fig. 4. Total and daily tourism expenditure of residents aged 65 or over, by the EU Member States, 2014 (source: Computed by authors. Data source: Eurostat news release 183/2016 from 26/o9/2016).

This may be explained by Romania's lower prices compared to the other EU Member States and could be exploited as an advantage by a targeted marketing strategy oriented towards inbound silver tourism.

A major factor determining tourism expenditure of residents aged 65 or over in Europe is definitely represented by their income, which is mostly generated by the pension system. The differences in European seniors' daily tourism expenditure are caused by the inequalities created by the pension values throughout the continent. The pensions in Romania (both old-age pension and total pension benefits as \% relative to GDP) are low compared with the EU average level (Fig. 5). In 2019, the average monthly pension in Romania was 1,292 RON (approximately 270 euro) compared with Germany (1.052 euro) or France (960 euro) (Davidson et al., 2015). If considering the median equivalised net income, the inequalities for older people in Europe are even higher. In 2017, Romania recorded a value of 5,082 PPS (purchasing power standards) far below the EU-28 average of 16,909 PPS. Even after considering price differences, the incomes of older people in Luxembourg are 6.1 times higher than those of older people living in Romania (Eurostat, 2020).

Romania's pension system also displays one of the most significant inequalities in Europe. In spite of the very high discrepancy in terms of median equivalised net 
income, the old-age pension benefits relative to GDP are below the European average (Fig. 5).

Romania's low figures for tourism expenditure of residents aged 65 or over may also be caused by the lack of attractive, varied, and adapted leisure and recreational services and products that could generate consumption by seniors. This explanation is also supported by the difference between the tourism expenditures of the elderly and the total average tourism expenditure, which registered a value of -12.4 EURO in 2014 for Romania (Eurostat, 2016a).

Pension benefits, 2017

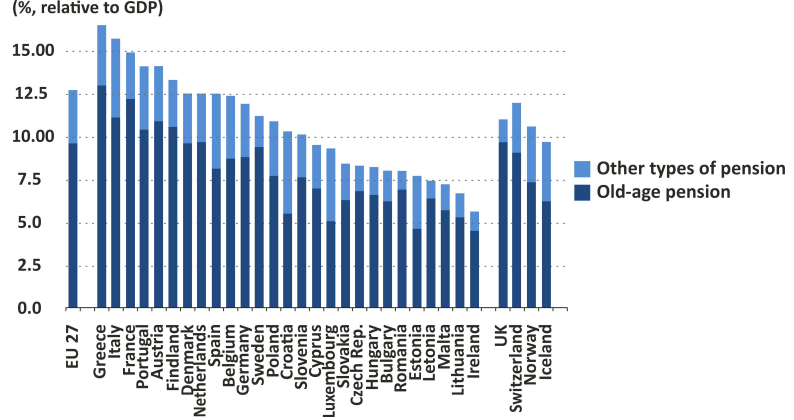

Fig 5. Pensions benefits in 2017 (data source: https://ec.europa.eu/eurostat/statistics-explained/index. php?title=Ageing_Europe_-_statistics_on_pensions, _income_and_expenditure).

The above figures indicate an unexploited potential for recreation and leisure tourism centred on senior demand for Romania, also considered in the larger European background. For a more accurate analysis and validation of silver tourism as a possible tourism resilience factor, the present paper was complemented by quantitative research among the elderly regarding their leisure consumption behaviour.

\subsection{Particularities for Romania}

Despite the continuous growth of the Romanian elderly population, the territorial attributes and improvements of infrastructure facilities destined for active ageing, recreational activities and leisure services are very limited (Elderly Population National Council, 2014). The development of silver tourism in Romania depends on the profound transformations of the leisure industry, which started in 1990 and characterised the post-communist period. In fact, the long and challenging privatisation process of hospitality structures and resorts in Romania led, in the absence of a coherent strategy, to the dissolution of previously successful tourism units and the decay of famous destinations, especially in the case of spa resorts (Erdeli et al., 2011; Gheorghilaş, Dincă and Surugiu, 2013).

This negative phenomenon fully impacted spa and medical tourism units. Romanian spa resorts already suffered from a lack of institutional involvement and cooperation. Instead, entrepreneurship initiatives' success was hindered by incoherent and fragmented tourism strategies (Lequeux-Dincă and Popescu, 2017). The quality of services registered a severe decline because of the defective management of both tourism infrastructure and natural resources used for medical purposes. Health resorts, developed due to the high value of their therapeutic resources, need to improve their tourism infrastructure (Gaman and Răcăşan, 2016) but also to restore their image (Lequeux-Dincă, Preda and Taloş, 2018). In Romania, spa tourism gradually overlapped with subsidised tourism (Aluculesei and Nistoreanu, 2014), targeting persons with lower income, including retirees, and consequently, it was negatively labelled, suffering from ageism connotations. As shown in the case of several Romanian successful destinations located in rural mountain areas (Mitrică et al., 2020), the recovery of tourism resorts in the post-COVID-19 period would depend on designing and promoting tailored products, supported by massive investments and the successful cooperation among stakeholders.

Governmental policies supporting seniors for recreational and/or leisure tourism activities mainly limit themselves to the programs of the National Public Pension House (abbreviated CNPP in Romanian), which grant vouchers for health treatments and relaxation, especially in spa resorts and prioritise specific categories of persons: those with severe medical injuries or disabilities and war veterans (CNPP, 2020).

According to the National Institute of Statistics (NIS), the number of such vouchers granted through the public social insurance system was a constant important segment of the tourism demand for domestic spa tourism in the post-communist decades. If in 1993 the state allocated 148,143 vouchers for spa destinations out of a total of over 193,000 social vouchers, the number reached a peak in the 2000-2003 period, with more than 330,000 vouchers granted yearly for spa resorts alone. After that moment, social vouchers for tourism purposes gradually declined, especially in 2010, due to the economic recession. The proportion of spa vouchers in the total number of social vouchers, granted through the national public insurance system, was constantly high (between 75\% and 95\%), and after 2012, it monopolised this market segment entirely. In 2019, 164,399 social vouchers were allocated for spa and medical resorts (NIS, 2021a, 2021b).

Access to unsubsidised tourism services is conditioned by income level, and most seniors end up spending their holidays in the cheaper mountain or rural boarding houses, as they do not have the budget to cover the expenditures of more suitable equipped accommodations. Private programs, like Senior Voyage, only offer cut off prices during the low season period or for certain international destinations (Info Turism, 2021). Domestic tourism packages are not dedicated 
particularly to the elderly but focus on price cuts, on social tourism and travelling during low season months, such as in the case of "The seaside for all" or "The holiday in the countryside" initiatives (FPTR, 2021a, 2021b) and so present incentive elements for seniors.

Besides the inadequate or lacking senior leisure tourism facilities, the recreation alternatives offered for older adults by the urban environment are also deficient. Urban infrastructure generally addresses all age categories, as local authorities do not prioritise adapting urban regeneration policies towards agefriendliness (Merciu and Merciu, 2014). Both seniors and the general population, regardless of age groups, end up using the same green areas in the urban or periurban zones or the outdoor sport and socialising areas for recreational purposes (Grigorescu and Geacu, 2017). In Bucharest municipality, there are only a few initiatives that address seniors exclusively. From the several clubs for seniors organised in the past by each District City Hall, only those from the 3rd and the 4th district are still functioning along with some other individual project initiatives supported by NGOs (DGASPC, 2020a, 2020b; Magic Seniors, 2020).

Private suppliers, such as NGO representatives, supplement the inadequate financing of the Romanian social services sector. Many times, their funding comes from grants of international donations (Mitran, 2015). The data provided by the Ministry of Work and Social Protection (2021) shows that in March of this year, out of the 997 entities licenced for providing social services-related activities, 917 were private suppliers. NGOs such as 4Change Association, Caritas Confederation, Yellow Cross Foundation, Habilitas Association, ADAM Association have always been pioneers for elderly's social support in Romania but focused mainly through their projects more on the elderly's accessibility to home care (Change Association, 2021) and less on recreational activities, meetings between its members on special occasions, themed meetings, and pilgrimages (Romania Caritas Confederation, 2021).

Among the recreational activities meant to improve life quality for the elderly in Romania, Magic Seniors NGO has at present four programs, some of them performed in partnership with themed clubs or associations in Bucharest (e.g. Romanian Federation of Scrabble): "Senior Cafe" (meetings among seniors); "Seniors Games" (introducing both seniors and youth to the world of socialisation games); "The Caravan with Stories: Tell Me a Story" (encouraging intergenerational dialogue); "Sport for Seniors" (Magic Seniors, 2020).

Despite certain initiatives in terms of silver tourism products and offers noticed at the EU level (e.g. DiscOver55 - uniting four European destinations on the common theme of "Water for Wellbeing"; EDEN55plusNW - developing cross-border tourism products; EUROSEN - Europe for Seniors - aiming to develop senior tourism in the low season; FY - Forever Young - focusing on transnational mobility and designing routes and products based on local cultural UNESCO heritage; GARDEN ROUTE - supporting relaxation in green spaces; LAKtive Tourism - focusing on senior target groups travelling in low and medium seasons to small lakeside towns; ESCAPE Charter for managing and maintaining quality standards related to seniors; ESCAPE Club - label and on-line platform; iESCAPE mobile application; Silver Suitcase card and label; Senior Rail Travel Project; SME tool kit for senior tourism products in SENTour Connect project) (Grahnlöf et al., 2016), both European and especially Romanian tourism products specifically destined to older adults are rather missing and represent a potential untapped by the hospitality industry.

\section{METHODOLOGY}

The present study proposes an empirical exploratory research of a novel and topical issue yet unexploited by the Romanian scientific literature. The research aims to obtain an initial input on the tourism behaviour of the elderly in Bucharest. Consequently, the research objectives were firstly to outline preferences regarding leisure tourism and recreational activities for the target group and secondly, to identify the most significant factors limiting their travelling for leisure purposes.

The research questions emerging from the general context and literature review on the topic are: what are the preferences of the elderly in Bucharest in terms of leisure activities and travelling? and which are the main barriers preventing seniors from travelling (more)?

The study methodology used complementary methods and was mainly based on a survey of a sample of residents aged 65 and over in Bucharest, living in all the city's districts (the age limit was chosen as the threshold of economic life per the Romanian legislation). The field research addressed equitability by randomly selecting seniors living in all six city districts to participate in the survey. The choice of Bucharest for this study was motivated by its rank of capital city, which means it is an important policymaking, economic and administrative centre and should display and benefit from the best age-friendly planning and project opportunities for the elderly.

In the end, 401 questionnaires were validated from a total of 410, as 9 respondents refused to answer all questions and interrupted the survey. The questionnaires were applied in October 2019 through the face-to-face interview method, to ensure the accuracy of data, the sample validation, and the reliability of the answers. 


\section{Ana-Maria TALOȘ, Ana-Irina LEQUEUX-DINCĂ, Mihaela PREDA, Camelia SURUGIU, \\ Alina MARECI, Iuliana VIJULIE \\ Journal of Settlements and Spatial Planning, Special Issue, no. 8 (2021) 29-48 \\ Territorial Identities and Sustainable Development. Challenges and Solutions}

The survey aimed mainly for quantitative information. It included: closed-ended questions on the variables defining respondents' profile (gender, age, education level and income); closed-ended questions that gathered precise data on the type and frequency of recreational activities that seniors practice; closedended questions on their preferences regarding leisure tourism activities, destinations, voucher options, holidaymaking period, booking options, but also about the main elements that prevent them from travelling away from their residential area or travelling more in general; open-ended questions aiming to obtain information about seniors' alternative options in terms of types of destinations, as well as on their motivating factors or barriers for leisure travelling.

The survey data were centralised and processed using dedicated software (SPSS 20) in order to gain territorial perspectives through descriptive analysis, crosstabs, and Pearson correlations. The authors used inferential analyses of the data based on the sample's choices, using variables such as income, education, holiday period, destination type, to find relevant results (Table 1 ).

Table 1. Respondents' profile.

\begin{tabular}{|c|c|c|c|c|c|}
\hline Gender & Percent & Frequency & Education & Percent & Frequency \\
\hline Male & 48.3 & 194 & Primary & 14.6 & 59 \\
\hline \multirow[t]{2}{*}{ Female } & 51.7 & 208 & Middle level & 59.3 & 238 \\
\hline & & & Superior & 26.1 & 105 \\
\hline Age & & & Income & & \\
\hline $65-70$ years & 52.2 & 210 & & & \\
\hline $70-75$ years & 25.9 & 103 & under 1,000 RON (€205) & 58.7 & 236 \\
\hline $75-80$ years & 14.2 & 57 & 1,000-2,000 RON (€205-€410) & 26.6 & 107 \\
\hline over 80 years & 7.7 & 32 & over 2,000 RON (€410) & 14.7 & 59 \\
\hline
\end{tabular}

Faculty of Geography, University of Bucharest.

Motivated by the novelty of this theme and by its territorial focus, the present study appealed to complementary research methods. Besides the abovedescribed survey, graphical methods (chart techniques), as well as map making methods (based on QGIS 2.12) were used in order to compute and illustrate relevant statistic data (selected from Eurostat and NIS).

Illustrated indices values for the EU Member States such as in the case of the share of tourism nights spent by people aged $65^{+}$out of all tourism nights, the weight of tourism nights spent by people aged $65^{+}$in domestic vs outbound trips, the total and the daily tourism expenditure of residents aged $65^{+}$helped the authors shape the background of silver tourism in Europe and contrast Romania's potential for this sector on a broader territorial context. The present study appealed to income indicators such as pension benefits as \% relative to GDP or the median equivalised net income for older people to explain the existing differences in terms of daily tourism expenditure of residents aged $65+$ among the EU states.

The volume of seniors' travelling, their current tourism expenditure but also their revenues and real income (confronted with the power of purchase and prices level) represent vital quantitative elements for characterising the silver tourism market status and predicting its development potential and may be a valuable starting point for future policymaking and tailored product design, thus explaining the authors' decision to include them in this study.

\section{RESULTS}

\subsection{Outlining elderly people preferences regarding leisure tourism and recreational activities}

The survey's main results regarding how the elderly spend their free time reveal quite a balanced, gradually decreasing proportion for performing recreational activities: during the weekend (30.3\%) to 3-4 days per week (28.5\%) and daily (25.5\%). The percentage for those performing recreational activities more often grows with their education level (Table 2).

The most frequent recreational activity for respondents is walking (52.1\%), followed by sports, visiting friends and relatives, reading or home-related activities, such as watching television, gardening and crafts (e.g. knitting).

The survey results reveal a moderate towards low consumption of traditional leisure tourism activities among older adults living in Bucharest, compared to the average European values that showed that in 2014, " $52 \%$ of EU residents aged 65 or more did not make any trip for personal purpose with at least one night away from home" (Demunter, 2016). Only 36.4\% of 
respondents declared to go on holiday yearly, and a percentage of $\mathbf{2 7 . 7 \%}$ mentioned leaving Bucharest for a holiday very rarely. Autochthonous silver tourism demand is clearly oriented towards domestic tourism and confirms the data shown previously in this study, as $63.3 \%$ of respondents prefer destinations in Romania.

The research results show that seniors' primary motivations for leaving on holiday are relaxation (35.9\%) and health treatments (32.2\%), followed by wanting to visit cultural attractions (13\%), mainly confirming the above-mentioned European trends. However, certain differences exist, as studies showed a more active profile for European senior holidaymakers (e.g. many ESCAPE respondents mentioned practising sport leisure activities such as swimming and hiking during their holidays, cf. Gheno, 2016). As expected, a higher number of those going on holiday motivated by health reasons belongs to the age group of 80 and over (38.8\%).

Table 2. Crosstab between education level and frequency of performing recreational activities.

\begin{tabular}{l|rrrrrr}
$\begin{array}{c}\text { Frequency of performing } \\
\text { recreational activities }\end{array}$ & $\begin{array}{c}\text { Daily } \\
(\boldsymbol{\%})\end{array}$ & $\begin{array}{c}\mathbf{3 - 4} \\
\text { days/week } \\
(\boldsymbol{\%})\end{array}$ & $\begin{array}{c}\text { During the } \\
\text { weekend } \\
(\%)\end{array}$ & $\begin{array}{c}\text { Not at all } \\
(\%)\end{array}$ & $\begin{array}{c}\text { DK/NA } \\
(\%)\end{array}$ & $\begin{array}{c}\text { Total } \\
(\%)\end{array}$ \\
\hline Education & & & & & & \\
Primary & 23.3 & 41.9 & 23.3 & 11.6 & 0.0 & 100 \\
Middle level & 25.1 & 25.1 & 33.3 & 13.0 & 3.4 & 100 \\
Superior & 27.6 & 29.5 & 32.4 & 8.6 & 1.9 & 100 \\
N/A & 24.4 & 28.9 & 17.8 & 24.4 & 4.4 & 100 \\
Total & 25.5 & 28.5 & 30.3 & 13.00 & 2.8 & 100
\end{tabular}

Spa resorts are preferred by $32.7 \%$ of respondents, followed by mountain destinations (26.7\%) and seaside resorts (18\%). However, the first category of destinations is partially overlapping with the other two, as important Romanian spa resorts are located both in mountain (e.g. Băile Herculane, Vatra Dornei) and seaside (e.g. Techirghiol, Eforie Nord) areas.

The preferences of Romanian seniors for specific tourism resorts are also conditioned by the quota of subsidised or free treatment vouchers allocated yearly by the government from an established list of destinations. In the sample group, $21.7 \%$ of respondents benefited from these vouchers, with more people belonging to the group with lower incomes (under 1,00o RON (205 EURO) /month) (22,2\%) compared to those belonging to the group with higher incomes over 2,000 RON (410 EURO) /month (18,5\%). This partially confirms the emphasised importance of social tourism for seniors from peripheral and low-income areas of Europe (TOURAGE report, 2014) but also suggests the acute need for market segmentation within the national and regional domestic silver tourism offer.

Most of the elderly in Romania mirror the European senior tourist profile (Grahnlöf et al., 2016) and choose to leave on holiday in the low season (46.2\%), against only $21.7 \%$ who leave during peak season. It is important to state that the high season months overlap with the warm summer months (July August) and that the percentage of seniors choosing a winter holiday, for example, is very low (5.2\%).

The correlation of the preferred holiday season with the income groups shows the need for segmenting the silver tourism offer and confirms the high potential of elderly holidaymakers to decrease seasonality. A high percentage $(48.3 \%)$ of those choosing the low season months for their holiday are those earning less than 1,000 RON (205 EURO)/month and 39\% of those earning between 1,000 RON (205 EURO) and 2,000 RON (410 EURO)/month.

The correlation between the preferred period for holidaymaking and income level underlines a significant positive relation $(\mathrm{r}=0.171, \mathrm{df}=401, \mathrm{p}<0.01)$, which shows that seniors with gradually higher-income leave on holiday on the more expensive months of the year and closer to tourism peak season (Table 3).

Table 3. Pearson correlation between income level and preferred period for a holiday.

\begin{tabular}{|l|l|r|r|}
\hline \multirow{2}{*}{ Income level } & \multicolumn{1}{|c|}{$\begin{array}{c}\text { Pearson } \\
\text { correlation }\end{array}$} & \multicolumn{1}{|c|}{$\begin{array}{c}\text { Income } \\
\text { level }\end{array}$} & $\begin{array}{c}\text { Preferred } \\
\text { holiday } \\
\text { period }\end{array}$ \\
\cline { 2 - 4 } & Sig. (2-tailed) & 1 & 0.171 \\
\hline $\begin{array}{l}\text { What holiday } \\
\text { period do you } \\
\text { prefer? }\end{array}$ & $\mathrm{N}$ & 401 & 0.001 \\
\hline $\begin{array}{l}\text { Correlation is } \\
\text { significant at } \\
\text { the } 0.01 \text { level } \\
\text { (2-tailed) }\end{array}$ & $\begin{array}{l}\text { Pearson } \\
\text { correlation }\end{array}$ & 0.171 & 401 \\
\hline & Sig. (2-tailed) & 0.001 & 1 \\
\hline & $\mathrm{N}$ & 401 & 401 \\
\hline
\end{tabular}

Like most of their European peers, seniors living in Bucharest prefer to organise their travel individually but also appeal to travel agencies to get 


\section{Ana-Maria TALOȘ, Ana-Irina LEQUEUX-DINCĂ, Mihaela PREDA, Camelia SURUGIU, \\ Alina MARECI, Iuliana VIJULIE \\ Journal of Settlements and Spatial Planning, Special Issue, no. 8 (2021) 29-48 \\ Territorial Identities and Sustainable Development. Challenges and Solutions}

informed about their travel options (TOURAGE report, 2014).

The correlation between education and booking preferences underlines a significant negative relation $(\mathrm{r}=-0.259, \mathrm{df}=401, \mathrm{p}<0.01)$, which shows that seniors with gradually lower education level prefer to use simple methods in order to choose and book their holiday (by themselves or with family help) instead of using a tourism agency as those with higher education frequently do. Booking through the CNPP system, based on a point system and prioritising certain disadvantaged categories of seniors, is also considered challenging and complicated by the elderly without digital skills, who may need support in handling digital platforms, regardless of whether this support comes for specialised agencies or family members. The need for help expressed by various categories of seniors when booking their holidays makes them a valuable element for ensuring the tourism sector's resilience, as the role and importance of travel agencies will only increase under the post-COVID-19 travelling conditions.

A percentage of 37.1 of those appealing to tourism agencies in order to book their holiday have superior studies, while children and relatives help an overwhelming percentage of $69.8 \%$ of those with primary education and $52.2 \%$ of those with middle-level education in making their bookings (Table 4). Extrapolations could be made with holiday preferences as the first category contains persons choosing expensive tourism packages, oriented towards seaside destinations for relaxing and entertaining activities. In contrast, respondents who choose alternatives to travel agencies for booking a holiday prefer cheaper weekend trips to mountains and rural areas or use spa vouchers.

Table 4. Crosstab between education and modality for choosing and making a holiday reservation.

\begin{tabular}{|c|c|c|c|c|c|}
\hline $\begin{array}{l}\text { Way of choosing } \\
\text { and making a } \\
\text { holiday reservation }\end{array}$ & $\begin{array}{c}\text { Alone } \\
(\%)\end{array}$ & $\begin{array}{c}\text { Travel agency } \\
(\%)\end{array}$ & $\begin{array}{l}\text { Other } \\
\text { (children, } \\
\text { friends, } \\
\text { neighbours) } \\
(\%)\end{array}$ & $\begin{array}{c}\text { DK/NA } \\
(\%)\end{array}$ & $\begin{array}{l}\text { Total } \\
(\%)\end{array}$ \\
\hline \multicolumn{6}{|l|}{ Education } \\
\hline Primary & 2.3 & 25.6 & 69.8 & 2.3 & 100 \\
\hline Middle level & 12.1 & 30.9 & 52.2 & 4.8 & 100 \\
\hline Superior & 31.4 & 37.1 & 24.8 & 6.7 & 100 \\
\hline $\mathrm{N} / \mathrm{A}$ & 17.4 & 19.6 & 45.7 & 17.4 & 100 \\
\hline Total & 16.7 & 30.7 & 46.1 & 6.5 & 100 \\
\hline
\end{tabular}

\subsection{Identifying the major factors which limit the elderly's travelling for leisure purposes}

According to Eurostat (2016b), the main barrier preventing senior European holidaymakers from travelling would be health problems (45.7\%), against a comparable value displayed by Romania (43.6\%), and the second is represented by financial problems (39.1\%).

Our research results show similarities to other studies, but the main internal limiting factor for the Bucharest elderly's leisure travelling is lack of money (48.9\%), with an expected larger extent within the group earning under 1,000 RON 205 EURO/month (54.6\%). This reason was followed by health problems (27.4\%). The differences showed by the Bucharest respondents compared to Eurostat values, which indicated in the first-place health reasons as a main limiting factor for Romanian seniors travelling (43.6\%), may be explained by better access to a great variety of healthcare services offered by the capital city compared to the rest of the country. In this way, health concerns are better addressed and less stressful for seniors in the capital city of Romania. A surprisingly third place is occupied by the lack of time (13.7\%), caused by our sample group's strong involvement in family care activities (grandchildren care), housing activities, or labour market. The lack of time as a limiting factor for the elderly with higher income $(40.7 \%$ of the respondents over 2,000 RON 410 EURO/month) is to be expected, as part of those declaring higher incomes still work, thus having less free time (Table 5).

When analysing the external limiting factors for travelling correlated with tourism destinations, it was observed that: $\mathbf{2 8 . 7 \%}$ of respondents mentioned the lack of senior designed and oriented layouts and access facilities (e.g. transport connections, building entrance and lift facilities); $24.2 \%$ mentioned the lack of proper recreational services/activities (e.g. adequate cultural or nature-oriented activities) and the lack of adequate dietary options - $19.5 \%$ - with most of these responses coming from those aged 80 or above.

The lack of layouts and access facilities is signalled as a problem mainly by older adults with primary education (48.8\%), frequently associated with lower revenues. As such, this category opts for less expensive destinations or hospitality units, which are not necessarily designed for senior needs and lack the 
basic comfort facilities suited for elderly consumers (e.g. space requirements for wheelchair access, adjustable furniture for elderly with functional limitations). Studies showed that the quality of services, the safety and transportation connections represent three of the five top concerns of EU senior tourists (TOURAGE report, 2014), which may see an increase in importance in the new post-COVID-19 context.

Table 5. Crosstab between education level and limiting travelling factors.

\begin{tabular}{|c|c|c|c|c|c|}
\hline $\begin{array}{c}\text { Reasons for not } \\
\text { travelling more } \\
\text { often }\end{array}$ & $\begin{array}{c}\text { Lack of money } \\
(\%)\end{array}$ & $\begin{array}{c}\text { Health } \\
\text { problems } \\
(\%)\end{array}$ & $\begin{array}{l}\text { Lack of time } \\
\quad(\%)\end{array}$ & $\begin{array}{c}\text { DK/NA } \\
(\%)\end{array}$ & $\begin{array}{l}\text { Total } \\
(\%)\end{array}$ \\
\hline \multicolumn{6}{|l|}{ Education } \\
\hline Primary & 67.4 & 25.6 & 2.3 & 4.7 & 100 \\
\hline Middle level & 56.0 & 23.7 & 11.6 & 8.7 & 100 \\
\hline Superior & 28.6 & 36.2 & 22.9 & 12.4 & 100 \\
\hline N/A & 45.7 & 26.1 & 13.0 & 15.2 & 100 \\
\hline Total & 48.9 & 27.4 & 13.7 & 10.0 & 100 \\
\hline
\end{tabular}

The lack of proper recreational services/activities (e.g. nature trips, visits to historical and religious sites, adapted sport and fitness activities) was a limiting factor, mainly for respondents with a superior education level (27.6\%). Choosing more expensive holiday packages in hospitality units adapted, in terms of senior-oriented facilities and comfort level, these respondents underline a general gap of the Romanian destinations, namely the lack of silver tailored recreational activities and programs. In the case of a tourism product, it is very important to consider its economic and social significance and correlate it with the efficient exploitation of resources and the domestic demand's satisfaction (Cocean and
Cocean, 2010). In the case of Romania, even though targeted silver products exist, they are only punctually offered by modern hotel units often found in spa resorts and are mostly those associated with healthcare facilities and services.

The crosstab between internal and external limiting factors for the elderly's leisure consumption reiterates the previous results and justifies the requirements for a segmented offer that can answer the differentiated needs of the future silver tourism market demand. The lack of money is the main barrier to travel for those preferring spa destinations, while the lack of time affects mostly seniors opting for seaside resorts (Table 6).

Table 6. Crosstab between favourite holiday destination and limiting travelling factors.

\begin{tabular}{|l|rr|rrr}
\multicolumn{1}{c}{$\begin{array}{c}\text { Reasons for not } \\
\text { travelling more } \\
\text { often }\end{array}$} & $\begin{array}{c}\text { Lack of money } \\
(\boldsymbol{\%})\end{array}$ & $\begin{array}{c}\text { Health } \\
\text { problems } \\
(\boldsymbol{\%})\end{array}$ & $\begin{array}{c}\text { Lack of time } \\
(\mathbf{\%})\end{array}$ & $\begin{array}{c}\text { DK/NA } \\
(\mathbf{\%})\end{array}$ & $\begin{array}{c}\text { Total } \\
(\%)\end{array}$ \\
\hline $\begin{array}{l}\text { Favourite holiday destination } \\
\text { Mountains }\end{array}$ & 51.4 & 22.4 & 12.1 & 14.0 & 100 \\
Seaside & 40.3 & 20.8 & 27.8 & 11.1 & 100 \\
SPA & 55.0 & 32.1 & 6.9 & 6.1 & 100 \\
Rural area & 51.6 & 28.1 & 14.1 & 6.3 & 100 \\
N/A & 25.9 & 40.7 & 14.8 & 18.5 & 100 \\
Total & 48.9 & 27.4 & 13.7 & 10.0 & 100 \\
\hline
\end{tabular}

\section{DISCUSSIONS}

One of the major findings of this study was that the leading cause for such a low proportion of the elderly in Bucharest leaving on holiday is the lack of money. Differing from the Eurostat (2016b) hierarchy, this reason largely overpasses the health issues, which comes second as a barrier preventing silver holidaymakers from travelling more often. In this context, it is important to mention that a significant part of retirees is currently employed in order to supplement their revenues. This is also proven by the high incidence of those choosing the weekend for recreational activities, regardless of their education level (see Table 2). The lack of money could be a sign that Romanian silver tourists are more prone to travel internally for holidays, which will help the local tourism market bounce back in the post-COVID-19 period. In addition to their being still economically active (as per the study respondents), this preference shows that:

- the tourism market for recreational activities (e.g. cultural events, amusement parks around 
Bucharest) is adapted more towards consumers who are employed or study, thus maximising their offers towards the weekend;

- the recreational activities are performed with family members of younger generations who facilitate access towards recreational areas surrounding Bucharest through personal transport means and impose their weekly activity pattern by conditioning their availability to their working schedule.

Seniors are also involved extensively in houserelated and family care activities, which create for them an important sense of social usefulness. Consequently, the availability of leisure time becomes limited for some categories of seniors and from one case to another.

Therefore, a more varied and complex offer of tourism products (including the social packages that today are almost entirely dominated by long-term treatment SPA vouchers) could be adapted towards encouraging seniors in Bucharest to participate to a greater extent in leisure tourism activities. For older adults, silver tourism activities represent, according to the Elderly Population National Council (2014), alternative ways but to a lesser extent to spend their free time. In their opinion, leisure activities for seniors include, besides trekking and backpacking trips, treatments and professional balneal, physiotherapy or kinesiotherapy procedures by qualified staff and adapted to individual medical conditions.

Considered as a major barrier for holidaymaking by the elderly in general, but also by seniors in Bucharest, health issues also represent a main travel motivation for the elderly and a product to be considered by future silver tourism offers. In Romania, spa tourism centres on its medical component and is mainly subsidised by the public insurance system. It represented for decades the dominant offer for retirees in Romania, meaning that the substantial differences in the interests and needs of those over 50 (EC, 2015) have been disregarded. Future resilience strategies and innovative silver tourism products need to orient towards more options for health and spa tourism to be considered in light of the active ageing principles.

Another issue to be considered refers to agefriendly planning for resorts and tourist facilities destined for silver tourism demand. The CNPP subsidised or free vouchers offered to low-income seniors in Romania are mainly allocated towards 2- and 3-star hotel units located in both spa resorts and seaside destinations, with the latter sometimes also having a spa profile (e.g. Eforie Nord, Techirghiol). Lacking major investments and suffering from a flawed privatisation process, these areas saw a notable decline in economic efficiency indicators and a decrease in the comfort rank of their hospitality units (especially those associated with medical treatment structures), which are mainly oriented towards the social voucher system (Erdeli et al., 2011).

The post-COVID-19 context and the limitations imposed on international travelling might represent an opportunity for the silver tourism domestic market if innovative, better adapted, and better-targeted products, destined to attract also higher-income categories of retirees who would normally prefer international destinations, would be designed, and promoted. Even if overpassed, the pandemic crisis will induce new travelling consumption patterns, and the cautious behaviour of seniors, as the most vulnerable age group to this new virus, is very probable to persist.

The long process of building psychologic resilience and overcoming travel fear for higher risk travel elements in the post-COVID context (e.g. air flight; unknown exotic destinations in developing countries) would orient all categories of seniors towards domestic leisure destinations. In this case, better governance measures and stakeholder collaboration would be essential elements to plan age-friendly areas and design appropriate silver supply offers in order to make them attractive and perceived as safe.

\section{CONCLUSIONS}

The analysis of seniors' preferences for leisure tourism and recreational activities is an important issue directly connected to active ageing goals. The results of the present study may help tourism planning policies and tour operator packages to better adapt to the elderly's needs by removing the barriers they encounter for leisure travelling purposes. Both recreational activities and leisure tourism may contribute to their mental and physical wellbeing, and as such, they could become a more important market share with the gradual increase of the elderly's percentage in the demographic structures of countries worldwide.

In Romania, senior-oriented tourism activities can become a substantial segment of the market if agefriendly, integrated, and adapted tourism resilience strategies will be put in place during the post-pandemic recovery process. Innovation and adaptation should be key concepts for tourism policymakers and tour operators that should design tailor-made offers and adopt age-friendly strategies for seniors to build travel resilience in the post-COVID-19 context. Increasing the confidence level and mitigating travel fear through attractive and safe tourist products are essential elements of the tourism resilience framework.

Income level clearly indicates a possible segmentation of leisure tourism products, dictating specific aspects of senior demand. The holidaymaking period, booking preferences, option for subsidised vouchers and even the preferences for different types of 
destinations were correlated distinctly according to this variable. Seniors with a higher income appeal to tourism agencies and choose to travel in the mid-season months, also opting for several holidays per year and weekend breaks.

CNPP vouchers, preferred by low-income categories, may also be diversified, and propose added value low-cost variables in terms of leisure activities in the attempt to better answer silver demand needs. As health status is also a major problem preventing senior holidaymakers from travelling more often, spa tourism remains a key product for silver tourists that should be shaped and further segmented to answer routine or special needs displayed by seniors with different income levels. The scarcity of adapted layouts and access facilities, dietary options, suitable programs, and recreational activities for seniors within different types of destinations and hospitality units are problems that must be focused on by the tourism industry. According to the present research results, the general improvement of tourism services destined for seniors, an adaptation of service and price variables according to the average pension level, and a simplification of the CNPP voucher granting system are major issues to be prioritised by future tourism policies.

At the same time, in the post-pandemic context, in which the development of domestic travelling and staycations would see a boost, agefriendly infrastructure and supply products should orient towards developing local recreational facilities for seniors. It is essential for travel agencies and tourism destinations to adapt their offer according to the travel preferences and needs of the potential growing number of consumers aged 65 and over while also considering the post-pandemic context and the current travel multi-objective sustainability issues and planning principles.

This paper makes an important contribution to the existing literature on the development potential for senior-oriented tourism activities in Romania and could be used as a point of departure for further studies and policies focusing on this leisure sector in the post-crisis period. This is even more prescient as scientists predict a pressured and urgent need to go back to business more aggressively and develop plans and policies in the attempt to recover damaged service industries and build resilient future solutions.

\section{ACKNOWLEDGEMENTS}

The research paper has benefitted from the support of the Romanian Young Academy, funded by Stiftung Mercator and the Alexander von Humboldt Foundation for the period 2020-2022.

The research has also benefited from DG EUROSTAT data and presentations of the Working
Group on Tourism of the AG D4, accessed through the participation at the Workshop "Towards an age-friendly tourism - Opportunities for the low-medium season”, 13 September 2016, DG GROW, European Commission. The authors are grateful to the journal editors and wish to thank the three referees for their detailed and constructive comments and suggestions that improved the earlier version of this paper.

Author Contributions: The authors equally contributed to this paper.

\section{REFERENCES}

Allan C. (1981), Measuring mature markets. American Demographics, 3, 13-17.

Aluculesei A.-C., Nistoreanu P. (2014), Empirical analysis of health tourism - Băile Herculane, WHERE TO? Balneo Research Journal, 5(4), 168-179. DOI: http://dx.doi.org/10.1268o/balneo.2014.1074.

Arbolino R., Boffardi R., De Simone L., Ioppolo G. (2021), Multi-objective optimisation technique: a novel approach in tourism sustainability planning. Journal of Environmental Management, 285. DOI: https://doi.org/10.1016/j.jenvman.2021.112016.

Arbulú I., Razumova M., Rey-Maquieira J., Sastre F. (2021), Can domestic tourism relieve the COVID-19 tourist industry crisis? The case of Spain. Journal of Destination Marketing \& Management, 20. DOI: https://doi.org/10.1016/j.jdmm.2021.100568.

Assaf A., Scuderi R. (2020), COVID-19 and the recovery of the tourism industry. Tourism Economics, 26(5), 731-733. DOI: https://doi.org/10.1177/1354816620933712.

Badoc-Gonzales B. P., Mandigma M. B. S., Tan J. J. (2021), Resilience and sustainability interventions in selected Post-Haiyan Philippines: MSMEs perspective. International Journal of Disaster Risk Reduction, $\quad 57, \quad$ DOI: https://doi.org/10.1016/j.ijdrr.2021.102162.

Banini T., Ilovan O.-R. (2021a), Introduction: dealing with territorial/place identity representations. In: Banini T., Ilovan O.-R. (eds.), Representing Place and Territorial Identities in Europe. GeoJournal Library, vol. 127. Springer, Cham, 1-19. DOI: https://doi.org/10.1007/978-3-030-66766-5_1.

Banini T., Ilovan O.-R. (2021b), Conclusions: towards a new agenda for place/territorial identity research. In: Banini T., Ilovan O.-R. (eds.), Representing Place and Territorial Identities in Europe. GeoJournal Library, vol. 127. Springer, Cham, 251-265. DOI: https://doi.org/10.1007/978-3-030-66766-5_17.

Branchik B. J. (2010), Silver dollars: The development of the US elderly market segment. Journal of Historic Research in Marketing, 2(2), 174-197. DOI: https://doi.org/10.1108/17557501011042542. 
Brouder P., Teoh S., Salazar N.B., Mostafanezhad M., Mei Pung J., Lapointe D., Higgins-Desbiolles F., Haywood M., Hall C. M., Balslev Clausen H. (2020), Reflections and discussions: tourism matters in the new normal post COVID-19. Tourism Geographies, 22(3), 735-746. DOI: https://doi.org/10.1080/14616688.2020.1770325.

Brown N. A., Rovins J. E., Feldmann-Jensen S., Orchiston C., Johnston D. (2017), Exploring disaster resilience within the hotel sector: a systematic review of literature. International Journal of Disaster Risk Reduction, 22, 362-370. DOI: https://doi.org/10.1016/j.ijdrr.2017.02.005.

Buckley R. (2020), Adjusting whitewater recreation and tourism to an ageing market. Journal of Outdoor Recreation and Tourism, 29. DOI: https://doi.org/10.1016/j.jort.2020.100280.

Cahyanto I., Wiblishauser M., Pennington-Gray L., Schroeder A. (2016), The dynamics of travel avoidance: The case of Ebola in the US. Tourism Management Perspectives, 20, 195-203. DOI: https:/doi.org/10.1016/j.tmp.2016.09.004

Change Association (2021), SenioriNET - Rețea ONG de servicii dedicate persoanelor vârstnice [SenioriNET the NGO network for services dedicated to the elderly]. URL: http://www.4change.ro/seniorinet-retea-ong-deservicii-dedic. Accessed on 29.02.2021.

Channer N. S., Hartt M., Biglieri S. (2020), Agingin-place and the spatial distribution of older adult vulnerability in Canada. Applied Geography, 125. DOI: https://doi.org/10.1016/j.apgeog.2020.102357.

Chao-zhi Z., Xiao-tao L. (2017), Tourism planning. In: Lowry L. (ed.), The Sage International Encyclopaedia of Travel and Tourism. SAGE Publications, Inc, 1253-1257. DOI: https://www.doi.org/10.4135/9781483368924.n459

Clarke A., Warren L. (2007), Hopes, fears and expectations about the future: what do older people's stories tell us about active ageing? Ageing and Society, 27(4), 465-488. DOI: https://doi.org/10.1017/So144686X06005824.

CNPP (2020), Ordinul nr. 265/22.10.2020. Criterii de acordare a biletelor de tratament balnear pe sistemul organizat şi administrat de Casa Națională de Pensii Publice [Criteria for granting SPA treatment tickets based on the system organized and managed by the National House of Public Pensions]. URL: https://www.cnpp.ro/documents/1018o/3801668/Crit erii\%2ode\%2otratament\%2obalnear\%20aprobate\%2oc u\%20ordinul\%20965\%20din\%2022.10.2020. Accessed on 5.02.2021.

Cocean R., Cocean P. (2010), Conceptual meanings of the spatial plan for the Sinaia - Braşov Region. Transylvanian Review of Administrative Sciences, 30E/ June, 97-103. https://rtsa.ro/tras/index.php/tras/article/view/170/1 66. Accessed on 1.02.2021.

Collins-Kreiner N., Ram Y. (2020), National tourism strategies during the Covid-19 pandemic. Annals of Tourism Research. DOI: https://doi.org/10.1016/j.annals.2020.103076 (in press).

Davidson H., Connolly K., McCurry J., Crouch D., Walker S., O'Hara M., Smith D., Kirchgaessner S., Penketh A., McDonald H. (2015), Which are the best countries in the world to grow old in? [Press Release]. URL: https://www.theguardian.com/society/2015/mar/o3/w hich-best-countries-grow-old-in-pensions-benefitshappiness. Accessed on 28.03.2021.

Demunter C. (2016), Tourism trends and ageing [PowerPoint presentation], DG EUROSTAT, Unit G-3 'Short-term business statistics; tourism', Workshop "Towards an age-friendly tourism - Opportunities for the low-medium season", 13 September 2016, DG GROW, European Commission. URL: https://ec.europa.eu/growth/content/workshop\%E2\%80\%98towards-age-friendly-tourismopportunities-low-and-medium-season\%E2\%80\%99O_en. Accessed on 15.02.2021.

DGASPC (2020a), Centrul de zi "Clubul seniorilor Covasna” [Codrii Neamţului Club for Seniors]. URL: http://www.dgaspc4.ro/servicii/centrul-de-zi--clubulseniorilor-covasna-. Accessed on 15.02.2021.

DGASPC (2020b), Clubul Seniorilor "Codrii Neamţului” [Codrii Neamțului Club for Seniors]. URL: https://dgaspc3.ro/centre-subordonate/protectiasociala/centre-destinate-persoanelor-varstnice/clubulseniorilor-codrii-neamtului/. Accessed on 15.02.2021.

Dolnicar S. (2005), Understanding barriers to leisure travel: tourist fears as a marketing basis. Journal of Vacation Marketing, 11(3), 197-208. DOI: https://doi.org/10.1177/1356766705055706.

Dolnicar S., Zare S. (2020), COVID19 and Airbnb Disrupting the disruptor. Annals of Tourism Research, 83. DOI: https://doi.org/10.1016/j.annals.2020.102961 Duhachek A., Iacobucci D. (2005), Consumer personality and coping: testing rival theories of process. Journal of Consumer Psychology, 15(1), 52-63. DOI: https://doi.org/10.1207/s15327663jcp1501_8.

Ehrlich K. (2016), SenGoR - Seniors Go Rural. A bottom-up, stakeholder-driven product for individual senior off-season travel using rural micro- and SMEs, established and managed through corporate agreements [PowerPoint presentation]. Workshop "Towards an age-friendly tourism - Opportunities for the low-medium season", 13 September 2016, DG GROW, European Commission. URL: https://ec.europa.eu/growth/content/workshop\%E2\%80\%98towards-age-friendly-tourism- 


\section{Silver Tourism and Recreational Activities as Possible Factors to Support Active Ageing and the Resilience of the Tourism Sector \\ Journal of Settlements and Spatial Planning, Special Issue, no. 8 (2021) 29-48 Territorial Identities and Sustainable Development. Challenges and Solutions}

opportunities-low-and-medium-season\%E2\%80\%99-

o_en. Accessed on 15.02.2021.

Elderly Population National Council (2014), Populaţia vârstnică a României la orizontul anului 2060 [Romania's elderly population at the dawn of 2060]. URL: $\quad$ http://cnpv.ro/wpcontent/uploads/2020/o3/Populatia-varstnica-aRomaniei-la-orizontul-anului-2060.pdf. Accessed on 15.02.2021.

Erdeli G., Dincă A.-I., Gheorghilaş A., Surugiu C. (2011), Romanian spa tourism: a communist paradigm in a post communist Era. Human Geographies, Journal of Studies and Research in Human Geography, 5(2), 41-56. DOI:

http://www.humangeographies.org.ro/articles/52/5_2_ 11_5_erdeli.pdf

ESPON (2019), ACPA - Adapting European Cities to Population Ageing: Policy Challenges and Best Practices, Final Report, Version 22/04/2020. URL: https://www.espon.eu/ACPA. Accessed on 21.02.2021.

European Commission (2015), The silver economy. Oxford Economics. URL: https://op.europa.eu/en/publication-detail//publication/a9efa929-3ec7-11e8-b5fe-01aa75ed71a1. Accessed on 15.03.2021.

European Commission (2018a), Silver Economy Study: How to Stimulate the Economy by Hundreds of Millions of Euros per Year, Report Study, 3 May 2018. URL: $\quad$ https://ec.europa.eu/digital-singlemarket/en/news/silver-economy-study-how-stimulateeconomy-hundreds-millions-euros-year. Accessed on 15.03.2021.

European Commission (2018b), What Is the European Innovation Partnership on Active and Healthy Ageing (EIP on AHA)? URL: https://ec.europa.eu/eip/ageing/about-the-

partnership_en.html. Accessed on 15.03.2021.

European Parliament and Council (2019), Directive (EU) 2019/882 of the European Parliament and of the Council of 17 April 2019 on the Accessibility Requirements for Products and Services (Text with EEA relevance). URL: https://eur-lex.europa.eu/legalcontent/EN/TXT/?uri=CELEX\%3A32019L0882.

Accessed on 15.02.2021.

Eurostat (2016a), News release 183/2016 from 26 September 2016, Presented during the Workshop "Towards an age-friendly tourism - Opportunities for the low-medium season", 13 September 2016, DG GROW, European Commission.

Eurostat (2016b), Main reasons reported for not participating in tourism by age group, 2016 (\%). https://ec.europa.eu/eurostat/statisticsexplained/index. php?title=File:Main_reasons_reported_for_not_partici pating_in_tourism_by_age_group,_EU-

28,_2016_(\%25).png\&oldid=389313. Accessed on 10.01.2021.
Eurostat (2019), Ageing Europe looking at the lives of older people in the EU. 2019 edition Luxembourg: Publications Office of the European Union. URL: https://ec.europa.eu/eurostat/statisticsexplained/index.php/Ageing_Europe_-

_looking_at_the_lives_of_older_people_in_the_EU. Accessed on 10.01.2021.

Eurostat (2020), Ageing Europe - statistics on pensions, income and expenditure. URL: https://ec.europa.eu/eurostat/statistics-

explained/index.php?title=Ageing_Europe__statistics _on_pensions,_income_and_expenditure. Accessed on 15.03.2021.

Fennell D. A. (2017), Towards a model of travel fear. Annals of Tourism Research, 66, 140-150. DOI: https://doi.org/10.1016/j.annals.2017.07.015.

Fotiadis A., Polyzos S., Huan T.-C. (2021), The good, the bad and the ugly on COVID-19 tourism recovery. Annals of Tourism Research, 87. DOI: https://doi.org/10.1016/j.annals.2020.103117.

FPTR (2021a), Federaţia Patronatelor din Turismul Românesc, Litoralul pentru toți [Seaside for all]. URL: http://www.fptr.ro/programe-fptr/litoralul-pentrutoti.aspx. Accessed on 10.02.2021.

FPTR (2021b), Federaţia Patronatelor din Turismul Românesc, Vacanțe la țără ANTREC [Holidays in the countryside ANTREC]. URL: http://www.fptr.ro/programe-fptr/vacante-la-taraantrec.aspx. Accessed on 10.02.2021.

Gaman G., Răcășan B. (2016), Transport accessibility as a factor for tourist flow augmentation. Case study: the Romanian health resorts. Journal of Settlements and Spatial Planning, 7(1), 65-7. DOI: https://geografie.ubbcluj.ro/ccau/jssp/arhiva_1_2016/ 07JSSP012016.pdf

Gheno I. (2016), The leverage of ESCAPE to tourists and operators [PowerPoint presentation]. Workshop "Towards an age-friendly tourism - Opportunities for the low-medium season", 13 September 2016, DG GROW, European Commission. URL: https://ec.europa.eu/growth/content/workshop\%E2\%80\%98towards-age-friendly-tourismopportunities-low-and-medium-season\%E2\%80\%99o_en. Accessed on 15.02.2021.

Gheorghilaş A., Dincă A.-I., Surugiu C. (2013), Phases of development of Romanian spa tourism destinations. Proceedings of the International Conference on Tourism (ICOT 2013), Trends, Impacts and Policies on Sustainable Tourism Development, Limassol, Cyprus, 5-8 June, 2013, 278-291. ISBN: 9789963-9799-2-9, ISSN: 1986-4256.

Gobin L. (2016), SENTour Connect Project, The EU Senior Travel Experience. [PowerPoint presentation]. Workshop "Towards an age-friendly tourism Opportunities for the low-medium season", 13 September 2016, DG GROW, European Commission. 
URL: https://ec.europa.eu/growth/content/workshop\%E2\%80\%98towards-age-friendly-tourismopportunities-low-and-medium-season\%E2\%80\%99O_en. Accessed on 15.02.2021.

Gössling S., Scott D., Hall M. (2020), Pandemics, tourism and global change: a rapid assessment of COVID-19. Journal of Sustainable Tourism. DOI: https://doi.org/10.1080/09669582.2020.1758708.

Grahnlöf K. G., Nybond P. A., Lif L., Pettersson R. (2016), Rapporteur Group EU Low Season Tourism Initiative Board EULSTIB, Final Report, Draft $15^{\text {th }}$ July 2016, Jämtland Härjedalen Turism.

Grigorescu I., Geacu S. (2017), The dynamics and conservation of forest ecosystems in Bucharest Metropolitan Area. Urban Forestry \& Urban Greening, 27, 90-99. DOI: http://www.sciencedirect.com/science/article/pii/S161 8866716304204

Guillemard A. M., Argoud D. (2004), France: A country with a deep early exit culture. In: Maltby T., de Vroom B., Mirabile M. L., Overbye E. (eds.), Ageing and the Transition to Retirement: A Comparative Analysis of European Welfare States. Ashgate, Aldershot, 165-185.

Haywood K. M. (2020), A post-COVID future: tourism community re-imagined and enabled. Tourism Geographies. An International Journal of Tourism Space, Place and Environment, 22(3), 299-609, DOI: https://doi.org/10.1080/14616688.2020.1762120.

Higgins-Desbiolles F. (2020), Socialising tourism for social and ecological justice after COVID-19. Tourism Geographies, 22(3), 610-623. DOI: https://doi.org/10.1080/14616688.2020.1757748.

Horea-Şerban R. I., Istrate M. (2015), Demographic vulnerabilities in the North-East Region of Romania during the post-communist period. Journal of Settlements and Spatial Planning, Special Issue (4), 173179. https://geografie.ubbcluj.ro/ccau/jssp/arhiva_si4_ 2015/o4JSSPSIo42015.pdf. Accessed on 02.02.2021.

Hudson S. (2010), Wooing zoomers: Marketing to the mature traveller. Marketing Intelligence and Planning, 28(4), 444-461.

DOI:

https://doi.org/10.1108/02634501011053568.

Info Turism (2021), Sejururi-programe varstnici [Holidays - programs for seniors]. URL: https://www.infoturism.ro/sejur/romania/programseniori. Accessed on 30.03.2021.

Kantola S., Uusitalo M., Nivala V., Tuulentie S. (2018), Tourism resort users' participation in planning: Testing the public participation geographic information system method in Levi, Finnish Lapland. Tourism Management Perspectives, 27, pp. 22-32. DOI: https://doi.org/10.1016/j.tmp.2018.04.001.

Lazer W. (1985), Inside the mature market. American Demographics, 7(3), 22-25.

Lee Y.-J. A., Kim J., Jang S., Ash K., Yang E. (2020), Tourism and economic resilience. Annals of
Tourism
hesearch.
https://doi.org/10.1016/j.annals.2020.103024.

DOI:

Lequeux-Dincă A. I., Popescu C. (2017), Institutional change and tourism development in postcommunist Romania. Proceedings book, II. International Conference on Tourism Dynamics and Trends Seville, Spain, 26-29 June 2017. Faculty of Tourism and Finance, University of Seville. ISBN: 97884-946883-2-4.

Lequeux-Dincă A. I., Preda M., Taloş A. M. (2018), Empirical evidences on foreign tourist demand perception of Bucharest. Almatourism, 9(17), 95-116. DOI: https://doi.org/10.6092/issn.2036-5195/7237

Lu S., Wei J. (2019), Public's perceived overcrowding risk and their adoption of precautionary actions: a study of holiday travel in China. Journal of Risk Research, 22, 844-864. DOI: https://doi.org/10.108o/13669877.2017.1422784 (7).

Ma T., Heywood A., MacIntyre C. R. (2021), Travel health seeking behaviours, masks, vaccines and outbreak awareness of Australian Chinese travellers visiting friends and relatives - Implications for control of COVID-19. Infection, Disease \& Health, 26(1), 38-47. DOI: https://doi.org/10.1016/j.idh.2020.08.007.

Magic Seniors (2020), Asociația Magic seniors [The Magic Seniors Association]. https://magicseniors.ro/cine-suntem/. Accessed on 15.02.2021.

Matei E., Saghin D., Dumitrache L., Nae M. (2018), Multidimensional approach on sustainability of ageing in Romanian residential care centers for elders. Sustainability, $\quad 10(9), \quad 3336 . \quad$ DOI: https://doi.org/10.3390/su10093336.

Merciu F. C., Merciu G. L. (2014), GIS solutions adapted to the needs of local public administration in the urban regeneration of the old centre of Petrosani municipality (Hunedoara county). Journal of Applied Engineering Sciences (JAES), 2(17), 60-66. https://cloud.uoradea.ro/index.php/s/dMCKzAxdxoW LG82\#pdfviewer

Ministry of Work and Social Protection (2021), Servicii Sociale pentru persoane vârstnice şi alte categorii de personae vulnerabile [Social services for the elderly and other categories of vulnerable persons]. URL: $\quad$ http://mmuncii.ro/j33/index.php/ro/2014domenii/familie/politici-familiale-incluziune-siasistenta-sociala/4848. Accessed on 29.03.2021.

Mitran L. (2015, June 17), ONG-uri: Peste 20\% din vârstnicii din România au nevoie de îngrijire la domiciliu, 0,23\% beneficiază [Over $20 \%$ of the elderly in Romania need home care, only $0.23 \%$ actually get it]. [Press Release]. URL: https://www.mediafax.ro/social/ong-uripeste-20-din-varstnicii-din-romania-au-nevoie-de-ingrijirela-domiciliu-o-23-beneficiaza-14466730. Accessed on 20. 03.2021. 
Mitrică B., Şerban P., Mocanu I., Grigorescu I., Damian N., Dumitraşcu M. (2020), Social development and regional disparities in the rural areas of Romania: focus on the social disadvantaged areas. Social Indicators Research, 152(1), 67-89. DOI: https://doi.org/10.1007/s11205-020-02415-7.

National Institute of Statistics (2020a), Arrivals of tourists accommodated in the structure of tourists reception by type of accommodation, type of tourists, macroregions, development regions and countries. URL: http://statistici.insse.ro:8077/tempo-

online/\#/pages/tables/insse-table. Accessed on 10.03.2021. National Institute of Statistics (2020b), Informații statistice. Seria statistica de turism [Statistical information. Tourism Data series]. URL: https://insse.ro/cms/sites/default/files/field/publicatii /seria_turism_tr1_2020.pdf. Accessed on 10.03.2021.

National Institute of Statistics (2021a), Bilete pentru tratament balnear şi odihnă acordate prin asigurările sociale [Tickets for balneary treatment and rest granted by means of social insurance]. URL: www.insse.ro. Accessed on 15.02.2021.

National Institute of Statistics (2021b), Bilete pentru tratament balnear şi odihnă acordate prin asigurările sociale de stat, pe staţiuni balneoclimaterice [Tickets for balneary treatment and rest granted by means of social insurance, by spa]. URL: www.insse.ro. Accessed on 15.02.2021.

Nikitina O., Vorontsova G. (2015), Aging population and tourism: socially determined model of consumer behavior in the "senior tourism" segment. Procedia Social and Behavioral Sciences, 214, 845-851. https://doi.org/10.1016/j.sbspro.2015.11.736

Nimrod G. (2008), Retirement and tourism themes in retirees' narratives. Annals of Tourism Research, 35(4), 859-878.

DOI:

https://doi.org/10.1016/j.annals.2008.06.001.

Novelli M., Gussing Burgess L., Jones A., Ritchie B. W. (2018), 'No Ebola...still doomed' - The Ebola-induced tourism crisis. Annals of Tourism Research, 70, 76-87. DOI: https://doi.org/10.1016/j.annals.2018.03.006.

Rahmafitria F., Pearce P. L., Oktadiana H., Putro H. P. H. (2020), Tourism planning and planning theory: Historical roots and contemporary alignment, Tourism Management Perspectives, 35 . DOI: https://doi.org/10.1016/j.tmp.2020.100703.

Romania Caritas Confederation (2021), SenioriNET. URL: https://caritasromania.ro/seniorinet/. Accessed on 28.02.2021.

Romāo J. (2020), Tourism, smart specialisation, growth, and resilience. Annals of Tourism Research, 84 . DOI: https://doi.org/10.1016/j.annals.2020.102995.

Schorr A. V., Khalaila R. (2018), Aging in place and quality of life among the elderly in Europe: a moderated mediation model. Archives of Gerontology and
Geriatrics, $\quad 77, \quad$ 196-204. DOI: https://doi.org/10.1016/j.archger.2018.04.009.

Sharma G. D., Thomas A., Paul J. (2021), Reviving tourism industry post-COVID-19: a resilience-based framework. Tourism Management Perspectives, 37. DOI: https://doi.org/10.1016/j.tmp.2020.100786.

Sigala M. (2020), Tourism and COVID-19: Impacts and implications for advancing and resetting industry and research. Journal of Business Research, 117, 312321.

DOI:

https://doi.org/10.1016/j.jbusres.2020.06.015.

Škare M., Soriano D. R., Porada-Rochon M. (2021), Impact of COVID-19 on the travel and tourism industry. Technological Forecasting \& Social Change, 163. DOI: https://doi.org/10.1016/j.techfore.2020.120469.

Shoemaker S. (1989), Segmentation of the senior pleasure travel market. Journal of Travel Research, 27(3), 14-21. DOI: https://doi.org/10.1177/004728758902700304.

Shoemaker S. (2000), Segmenting the mature market: 10 years later. Journal of Travel Research, 39(1), 11-26. DOI: https://doi.org/10.1177/004728750003900103.

Strong P. (1990), Epidemic psychology: a model. Sociology of Health \& Illness, 12(3), 249-259. DOI: https://doi.org/10.1111/1467-9566.ep11347150.

Thanthong-Knight R. (2020, August 31), Thailand plans re-opening for long-stay visitors this winter. [Press Release]. URL: https://www.bloombergquint.com/globaleconomics/thailand-plans-re-opening-for-long-stayforeigners-this-winter. Accessed on 28.03. 2021.

TOURAGE Report (2014), What are the needs of senior tourists in TOURAGE regions? Report on the results of the questionnaire for local seniors on tourism, February 2014. INTERREG IVC Project „Developing Senior Tourism in Remote Regions" (TOURAGE). Edited by Szabolcs-Szatmár-Bereg County Regional Development and Environmental Management Agency/Észak-Alföld Regional Development Agency Nonprofit ltd.

Varnai P., Simmonds P., Farla K., Worthington H. (2018), The Silver Economy - Final Report. A study prepared for the European Commission DG Communications Networks, Content \& Technology by Technopolis Group, Oxford Economics. DOI: https://doi.org/10.2759/685036.

Walker A. (2010), The emergence and application of active ageing in Europe. In: Naegele G. (ed), Soziale Lebenslaufpolitik, VS Verlag für Sozialwissenschaften, Wiesbaden [Social Life Course Policy], 585-601. DOI: https://doi.org/10.1007/s10433-013-0261-0.

Wen Z., Huimin G., Kavanaugh R. R. (2005), The Impacts of SARS on the Consumer Behaviour of Chinese Domestic Tourists. Current Issues in Tourism, 8(1), 22-38. DOI: https://doi.org/10.1080/13683500508668203. 
Wearing B. (1995), Leisure and resistance in an ageing society. Leisure Studies, 14(4), 263-279. DOI: https://doi.org/10.1080/02614369500390201.

World Health Organization (WHO) (2002), Active Ageing: A Policy Framework. WHO, Noncommunicable Diseases and Mental Health Cluster, Noncommunicable Disease Prevention and Health Promotion Department, Ageing and Life Course. URL: https://apps. who.int/iris/bitstream/handle/10665/67215/WHO_NMH _NPH_02.8.pdf;jsessionid $=376236 \mathrm{CE} 88 \mathrm{CAC} 5 \mathrm{~B} 85 \mathrm{~B} 5 \mathrm{CBF}$ E9380A4659?sequence=1. Accessed on 11.02. 2021.

World Health Organization (WHO) (2007), Global Age-friendly Cities: A Guide. WHO, Ageing and Life Course, Family and Community Health. URL: https://www.who.int/ageing/publications/Global_age _friendly_cities_Guide_English.pdf. Accessed on 09 . 02.2021.

World Health Organization (WHO) (2015), World Report on Ageing and Health. Geneva: World Health Organization. URL: https://www.who.int/ageing/events/world-report-2015launch/en/. Accessed on 5.02. 2021.

World Health Organization (WHO) (2019), Decade of Healthy Ageing 2020-2030. URL: https://www.who.int/docs/default-source/decade-ofhealthy-ageing/final-decade-proposal/decadeproposal-final-apr2020-en.pdf. Accessed on 2.02.2021.

World Tourism Organization (UNWTO) (2020a), Tourism and COVID-19, 13 March 2020. URL: https://webunwto.s3.eu-west-1.amazonaws.com/s3fspublic/2020-04/COVID19_NewDS_.pdf. Accessed on 10.02.2021.

World Tourism Organization (UNWTO) (2020b), International tourism numbers could fall $60-80 \%$ in
2020 [Press Release 7 May 2020]. URL: https://www.unwto.org/news/covid-19-internationaltourist-numbers-could-fall-6o-80-in-2020. Accessed on 10.03.2021.

World Tourism Organization (UNWTO) (2020c), Billions [Press Release 28 January 2021]. URL: https://www.unwto.org/news/2020-worst-year-intourism-history-with-1-billion-fewer-internationalarrivals. Accessed on 10.03.2021.

World Travel, \& Tourism Council (2018), Impact of the Ebola Epidemic on Travel and Tourism. URL: https://wttc.org/Portals/o/Documents/Reports/2018/ Impact\%20of\%20the\%2oEbola\%20epidemic\%20on\%2 oTravel\%20and\%20Tourism\%202018.pdf?ver=202102-25-182521-103. Accessed on 25.02.2021.

Yu J., Rosenberg M. W. (2020), Aging and the changing urban environment: the relationship between older people and the living environment in post-reform Beijing, China. Urban Geography, 41(1), 162-181. DOI: https://doi.org/10.1080/02723638.2019.1643172.

Yusuf M. A., Ari R., Kisnarini R., Septanti D., Santosa H. R. (2019), Planning for sustainable tourism. Case study: Kampung of Cookies, Surabaya, Indonesia. Journal of Settlements and Spatial Planning, 10(1), 49-6o. DOI: https://doi.org/10.24193/JSSP.2019.1.05.

Zhang H., Song H., Wen L., Liu C. (2021), Forecasting tourism recovery amid COVID-19. Annals of Tourism Research, 87. DOI: https://doi.org/10.1016/j.annals.2021.103149.

Zheng D., Luo Q., Ritchie B. W. (2021), Afraid to travel after COVID-19? Self-protection, coping and resilience against pandemic 'travel fear'. Tourism Management, $83 . \quad$ DOI: https://doi.org/10.1016/j.tourman.2020.104261. 